\section{Effects of epidermal growth factor in artificial tear on vitamin $C$ levels of corneal wounded eye tissues}

\begin{abstract}
Purpose To investigate the effect of artificial tear (AT) solution and epidermal growth factor (EGF) treatment on the cornea and aqueous humour ascorbic acid (AA) levels of fullthickness corneal wounded eyes.

Methods The effect of EGF on the AA levels of aqueous humour and corneal wound tissue was determined in full-thickness corneal wounded rabbit eyes on the seventh postoperative day. There were three groups: untreated controls, AT-treated controls and an $E G F+A T$-treated experimental group ( $n=6$ in each group). Corneal wounded eyes were topically treated with $5 \mu$ I AT or $5 \mu$ l EGF in AT $(1 \mathrm{mg} / \mathrm{l}$ EGF in AT prepaaration which contained $3.0 \%$ carbopol 940 ) twice daily for 6 days after operation. The wound strengths were also measured on the seventh postoperative day as a measure of wound healing. Statistical analysis was carried out using the Mann-Whitney $U$-test by Statview program. Results The wound strengths of corneas, and AA levels of wound tissues and aqueous humour, increased significantly following AT and EGF treatment $(p<0.05)$.

Conclusion In the corneal wounded eye, aqueous humour serves as a source of vitamin $C$ and there may be a relation between EGF treatment in AT and AA levels of corneal wounded eye tissues.
\end{abstract}

Key words Aqueous humour, Artificial tears, Ascorbic acid, Corneal wound healing, EGF, Rabbit

\section{Introduction}

Ascorbic acid (AA) is found throughout the eye of many species in high concentrations relative to most other tissues. ${ }^{1}$ AA concentrations of some ocular tissues in diurnal animals are 20-70 times that of the plasma. ${ }^{2}$ Concentrations up to $3 \mathrm{mmol} / \mathrm{l}$ are reported in aqueous humour and the lens. ${ }^{3}$ High AA levels in aqueous humour and intraocular tissues including the lens and cornea are thought to protect against the harmful effects of the photochemical and ambient oxidation reactions involving oxygen and its radicals. ${ }^{4} \mathrm{AA}$ is supplied to the eye from the plasma. The ciliary body transports AA across the blood-aqueous barrier into the aqueous humour. ${ }^{5}$ It is generally thought that the aqueous humour serves as a source of AA for all other ocular tissues. Numerous studies in many cell types and tissues have defined roles for AA in protein and catecholamine biosynthesis, in collagen, lipid and iron metabolism, in hormone activation and as an antioxidant. $^{6}$

The role(s) of AA in wounded ocular tissues has not been widely studied and is even less understood. The millimolar concentrations present in each of the ocular tissues certainly argues for an important function. A high concentration of ascorbate in the eye may be an adaptation that protects the eye against solar radiation. ${ }^{3}$ AA decreases the photoperoxidation of the membranes in the lens. ${ }^{7}$ In human cataractous lenses, it was reported that AA is dramatically reduced. In persons taking supplementary vitamin $C$ alone, or vitamin $C$ and $E$ in combination, senile cataract risk is reduced by approximately $70 \%$. Antioxidants may also be effective in preventing diabetic cataractogenesis. ${ }^{8}$ In case of wounding, tissue is in need of more AA than for normal tissue activities and AA deficiency impairs collagen synthesis. ${ }^{9}$ In an attempt to identify an agent which would accelerate corneal wound healing, Pfister and co-workers tested the effect of subcutaneous injections of ascorbate, a vitamin necessary for collagen synthesis, on the tensile strength of corneal lacerations in vitamin Cdeficient rabbits with mild-alkali-burned eyes or normal eyes. Parenterally administered ascorbate had no beneficial effect on the tensile strength of corneal wounds in normal rabbit eyes but did significantly increase the tensile strength of wounds in mild-alkali-burned
B. Gönül

B. Kaplan

M.T. Budak

Department of Physiology Gazi University Faculty of

Medicine

Ankara, Turkey

K. Bilgihan

Department of

Ophthalmology

Gazi University Faculty of

Medicine

Ankara, Turkey

Prof. Dr. Bilge Gönül Department of Physiology Gazi University Faculty of Medicine

Beşevler, Ankara

Turkey, 06500

Tel: +90 3122128132

Fax: +903122354119

e-mail: hbcgonul@turk.net

Preliminary results

previously presented at the Eighth Biennial Meeting of the International Society for Free Radical Research, Barcelona, Spain, 1996

Supported in part by Gazi University Research

Foundation

Received: 1 February 2000 Accepted in revised form: 20 October 2000 
eyes. ${ }^{10}$ Saika and co-workers' observations also support a therapeutic role for ascorbate in the repair of corneal stromal damage. ${ }^{11}$

Epidermal growth factor (EGF) is a single polypeptide chain and contains three disulphide bonds. EGF stimulates corneal epithelial wound healing. Local daily application of EGF enhances epithelial cell mitosis, accumulation of granulation tissue cells, collagen and glycosaminoglycans in experimental rat wounds. ${ }^{12}$ It was reported that peptide growth factors such as platelet derived growth factor (PDGF), EGF, fibroblast growth factor a (aFGF) and fibroblast growth factor $b$ (bFGF) are able to increase keratocyte migration. When released during tissue damage, they may undertake the task of recruiting keratocytes from adjacent stroma to invade the wound, where remodelling and reconstruction of the damaged site is carried out. ${ }^{13}$ Topical application of EGF increases the tensile strength of full-thickness corneal incisions in rabbits. ${ }^{14}$

Several factors combine to suggest that a controlledrelease delivery system of EGF will enhance its effectiveness. Repeated or prolonged administration is necesary for effective therapy. ${ }^{15}$ Studies report on the use of liposomes, lipid-surfactant micelles, oil vehicles, emulsions, microemulsions, etc., for drug delivery. ${ }^{16}$ Carbopol 940 preparations are developed as long-lasting artificial tears (AT) for the relief of dry eye syndrome and traumatic injury. We have previously identified the positive effects of AT solutions on wound healing by topical treatment. ${ }^{17}$

This study was planned to observe the effect of EGF in an AT preparation on the corneal wound healing and the AA status of related eye tissues.

\section{Materials and methods}

Animals

Adult male and female (total 36) New Zealand albino rabbits weighing $1.5 \pm 0.5 \mathrm{~kg}$ were used, in compliance with the ARVO Resolution on the Use of Animals in Research. Animals were placed in separate cages. They were maintained at $20 \pm 2{ }^{\circ} \mathrm{C}$ in a daily light/dark cycle and were fed with a normal diet and vegetables for 7 days prior to operation for adaptation to the laboratory conditions. They were kept in the same conditions after the operation for 6 days. Experiments were done in the summer.

\section{Experimental protocol}

There were three groups of 12 animals each:

1. Untreated controls

2. AT treatment, $5 \mu$ l twice a day, for 6 days

3. EGF treatment in AT solution $(1 \mathrm{mg} / \mathrm{l}) 5 \mu \mathrm{l}$ twice a day, for 6 days

Rabbits were anaesthetised by intramuscular injection of mixed ketamine + xylazine $(35 \mathrm{mg} / \mathrm{kg}, 5 \mathrm{mg} / \mathrm{kg})$ and topical propacain before wounding. Five millimetre long corneal full-thickness wounds were made horizontally with a surgical blade in the middle of the cornea of the right eye, causing loss of aqueous humour, under direct visualisation through an operating microscope. The wounds were closed by one suture in the middle of the incision. The topical therapy started on the same day as the surgery. Thilo-Tears (Dr Thilo-Co Combh, Alcon, Couvreur, Belgium; $1 \mathrm{~g}$ gel contains $3 \mathrm{mg}$ carbomer, $50 \mathrm{mg}$ mannitol, $0.04 \mathrm{mg}$ thiomersal, $945.712 \mathrm{mg}$ distilled water) AT preparation was used as vehicle for EGF (Sigma, E 7755, from mouse submaxillary gland; $1 \mathrm{mg} / \mathrm{l}$ was the final EGF concentration in AT solution). ${ }^{18}$ Operated eyes were treated for 6 days as detailed above. On the seventh day after the operation the tensile strength of the wounds was studied together with the increase in intraocular pressure in 18 rabbits from the three groups under anaesthesia. The eye tissues are soft and the fluids in aqueous form in the living animal. Application and sampling are easier under anaesthesia. Under visualisation through an operating microscope (Olympus SZ-PT), a 25-gauge disposable needle was inserted through the perilimbal clear cornea at the 6 o'clock meridian into the anterior chamber. The needle was connected by plastic tubing to a pressure transducer (P23 XL High Pressure Transducer) and a pump (Eyela Microtube Pomp MP-3). The sutures were removed. Buffered saline was pumped into the anterior chamber at a speed of $5 \mathrm{ml} / \mathrm{min}$ and the output of the pressure transducer was recorded on a polygraph (Grass model 7). ${ }^{19,20}$ Then the rabbits were killed with an overdose of intravenous pentobarbital sodium.

AA levels of the corneal wound and aqueous humour were studied as previously described by Berger and coworkers. ${ }^{20}$ Corneal tissue strips of the other 18 rabbits were excised immediately (one strip $15 \mathrm{~mm}$ in length and $3 \mathrm{~mm}$ in width was cut out of the centre of the cornea, with the long axis perpendicular to the wound) and thawed at $0{ }^{\circ} \mathrm{C}$, weighed, and homogenised on ice in 9 volumes of $0.35 \mathrm{M}$ perchloric acid with $0.1 \mathrm{mg}$ EDTA $/ \mathrm{ml}$ (PCA/EDTA) by Heidolph Diax 600 disperser. Samples were centrifuged at $15000 \mathrm{~g}$ for $3 \mathrm{~min}$ at $4{ }^{\circ} \mathrm{C}$ and supernatants were obtained. Aqueous humour was combined with an equal volume of PCA/EDTA and centrifuged as above. In the study each sample was analysed at least twice (intra-class correlation coefficient of repeatability was 0.96 ). Total ascorbate was determined by the modified Roe and Keuther method. A portion of $200 \mu \mathrm{l}$ of standard and sample in a centrifuge tube was combined with $50 \mu$ l colour reagent $(0.6 \%$ copper sulphate, $5 \%$ thiourea and 2,4dinitrophenylhydrazine, 1:1:20, v:v:v). After keeping samples for $3 \mathrm{~h}$ at $37^{\circ} \mathrm{C}$ in a waterbath, they were cooled to $0{ }^{\circ} \mathrm{C}$ and $300 \mu \mathrm{l}$ of $65 \%(\mathrm{v} / \mathrm{v})$ sulphate acid was added. The samples were vortexed, and the optical density at $515 \mathrm{~nm}$ was measured.

As there were 6 animals in each group, statistical analysis was carried out using the Mann-Whitney $U$-test with Statview program. $p<0.05$ was considered to be significant. 
Table 1. Effect of EGF treatment on the tensile strength of corneal wounds on the seventh post-operative day

\begin{tabular}{llc}
\hline Group & $n$ & Wound tensile strength $(\mathrm{mmHg})$ \\
\hline Control & 6 & $340 \pm 10.1$ \\
AT & 6 & $550 \pm 10.9^{a}$ \\
EGF + AT & 6 & $701 \pm 51^{a, b}$
\end{tabular}

The results are expressed as mean \pm SD.

${ }^{a}$ Significant difference from the control group $(p<0.05)$.

${ }^{b}$ Significant difference from the AT group (Thilo-Tears, $5 \mu \mathrm{l}$ twice a day) $(p<0.05)$.

EGF was prepared in Thilo-Tears gel $1 \mathrm{mg} / 1$ and applied topically $5 \mu \mathrm{l}$ twice a day to the wound for 6 days; experiments were carried out on the seventh post-operative day.

\section{Results}

In this study, the healing rate of the EGF-treated corneal wounds is shown by the tensile strength of the wound, compared with the untreated group. At the end of the treatment, the tensile strength of the EGF+AT-treated corneal wounds was compared with that of the control wounds, along with aqueous humour and corneal wound tissue AA levels.

The tensile strength of the AT-treated eyes was higher than that of the controls. EGF treatments in AT also increased the average intraocular pressure causing rupture of the full-thickness corneal wound. Pressures increased from $340 \mathrm{mmHg}$ in controls to $550 \mathrm{mmHg}$ in the AT-treated group and to $701 \mathrm{mmHg}$ in the EGF+ATtreated group on the seventh post-operative day (Table 1).

AA levels in the tissues of corneal wounded eyes after 7 days of topical AT and EGF+AT treatment were determined and compared with controls (Table 2). The aqueous humour and corneal wound tissue AA levels of EGF-treated eyes were higher than those of the controls on the seventh post-operative day $(p<0.05)$.

\section{Discussion}

The wound healing process is composed of various components. One of them is the restoration of tensile strength through collagen synthesis. Collagen provides the strength and integrity of all tissues, repaired with the cross-linking and deposition of collagen. The tensile strength of healing wounds in situ is generally recognised as a reflection of the rate of repair. ${ }^{21}$ Corneal epithelial

Table 2. The effects of EGF treatment on aqueous humour and corneal wound tissue AA levels on the seventh post-operative day

\begin{tabular}{lccc}
\hline & & \multicolumn{2}{c}{ AA level } \\
\cline { 3 - 4 } Group & $n$ & $\begin{array}{c}\text { Aqueous humour } \\
(\mathrm{mM})\end{array}$ & $\begin{array}{c}\text { Corneal wound } \\
(\mathrm{mg} / \mathrm{g})\end{array}$ \\
\hline Control & 6 & $16.7 \pm 0.9$ & $0.16 \pm 0.05$ \\
AT & 6 & $18.2 \pm 6.6$ & $0.46 \pm 0.07$ \\
EGF + AT & 6 & $34.4 \pm 15^{a}$ & $1.35 \pm 0.2^{a}$ \\
\hline
\end{tabular}

The results are expressed as mean $\pm \mathrm{SD}$.

${ }^{a}$ Significant difference from the control group and AT group (Thilo-Tears, $5 \mu \mathrm{l}$ twice a day) $(p<0.05)$

EGF prepared in Thilo-Tears gel $1 \mathrm{mg} / \mathrm{l}$ and applied topically 5 $\mu l$ twice a day to the wound. wound repair involves reorganisation, migration and proliferation of the epithelial cells. It has been reported that EGF facilitates corneal epithelial wound repair by increasing migration and mitosis of cells. ${ }^{13}$

EGF, in solution form, enhances the accumulation of granulation tissue cells and collagen ${ }^{12}$ and supports corneal wound healing. ${ }^{22,23}$ Like most peptides, EGF is unstable in physiological fluids and has a very short halflife. ${ }^{15}$ EGF in solution form is diluted and washed by tears following topical application to corneal surfaces. Additionally, it is hypothesised that high concentrations of EGF may induce receptor downregulation, and hence result in a reduced therapeutic effect. ${ }^{15}$ On the other hand, topical EGF treatments in low doses but for long exposure times improve wound healing. ${ }^{17}$ In this study we hypothesised that more effective therapy might be achieved with a drug delivery system capable of administering EGF directly to the wound site, if the optimal concentration could be maintained for a prolonged duration. In our previous wound healing studies we used carbopol 940 gels as a drug delivery system. ${ }^{17,23}$ Previously, we compared the effects on corneal wounds of AT preparations which are based on carbopol 940, and then observed over 15 days the local treatment effects of AT gels by wound strength and histological examination. ${ }^{19}$ Because of the positive effect of Thilo-Tears on wound strength, we chose Thilo-Tears as a vehicle for EGF in this study. The AT preparation forms a film on the corneal surface by dilution with tears and shows bioadhesion to conjunctival epithelium. ${ }^{24}$ Active substances carried with this polymer are released by diffusion. ${ }^{25}$ Topical EGF treatment twice a day, with this gel form of artificial tears, increased the intraocular pressure causing rupture of full-thickness corneal wounds compared with other groups. The pressure was higher in the EGF+AT-treated group than in the control and AT-treated groups. This result supports Zhang et al.'s study which indicates that topical EGF treatment in carbopol gel stimulates corneal wound repair. ${ }^{26}$ Increased intraocular pressure causing rupture in EGF+AT-treated wounded eyes may be related to collagen deposition at the wound site. EGF increases the synthesis of fibronectin and collagen in fibroblasts. ${ }^{27}$

In the synthesis of collagen, AA plays a key role in wound healing. AA accumulates in the eye, with active transport through the iris-ciliary body into the aqueous humour, and subsequent transport into the lens and cornea. ${ }^{28}$ Thus, aqueous humour serves as a source of AA for other ocular tissues. ${ }^{12,29}$ In this study corneal wound AA levels increased with treatment by EGF+AT. Aqueous humour levels of AA also increased in the same manner with the same treatment. This can be related to AA transport to the wounded cornea from aqueous humour $^{2}$ due to increased AA requirements of the wound following stimulation of the healing processes by EGF. ${ }^{1,30}$ Increased AA levels of the corneal wound tissues and aqueous humour were affected by EGF treatment and these observations are supported by the results of tensile strength experiments. 
In conclusion, this study's results show firstly that aqueous humour serves as a source of vitamin $C$ for wounded cornea and secondly that there may be a relation between treatment with EGF in artificial tears, or treatment with artificial tears alone, and AA levels of corneal wounded eye tissues.

\section{References}

1. Kodama T, Kabasawa I, Tamura O, Reddy VN. Dynamics of ascorbate in the aqueous humor and tissues surrounding ocular chambers. Ophthalmic Res 1985;17:331-7.

2. Reiss GR, Werness PG, Zollman PF, Brubaker RF. Ascorbic acid levels in the aqueous humor of nocturnal and diurnal mammals. Arch Ophthalmol 1986;104:753-5.

3. Garland DL. Ascorbic acid and the eye. Am J Clin Nutr 1991;54:S1198-202.

4. Bielski BHJ. Chemistry of ascorbic acid radicals. Adv Chem Ser 1982;200:81-100.

5. Di Mattio J. A comparative study of ascorbic acid entry into aqueous and vitreous humors of the rat and guinea pig. Invest Ophthalmol Vis Sci 1989;30:2320-31.

6. Padh H. Cellular functions of ascorbic acid. Biochem Cell Biol 1978;68:1166-73.

7. Rigvold A. Aqueous humor and ultraviolet radiation. Acta Ophthalmol Scand 1980;58:69-82.

8. Linklater HA, Dzialoszynski T, McLeod HL, Sanford SE, Trevithick JR. Modelling cortical cataractogenesis. XI. Vitamin C reduces gamma-crystallin leakage from lenses in diabetic rats. Exp Eye Res 1990;51:2421-47.

9. Levenson S, Seifter E, Van Winkle E Jr. In: Hunt TK, Dunphy JE, editors. Fundamentals of wound management. New York: Appleton-Century-Crofts, 1979:286-363.

10. Pfister RR, Hayes SA, Paterson CA. The influence of parenteral ascorbate on the strength of corneal wounds. Invest Ophthalmol Vis Sci 1981;21:80-6.

11. Saika S, Uenoyama K, Hiroi K, Ooshima A. Effect of L-ascorbic acid 2-phosphate on cultured rabbit keratocyte. III. The effect on production and secretion of type 1 collagen. Nippon Ganka Gakkai Zasshi-Acta Soc Ophthalmol Jpn 1991;95:835-40.

12. Laato M, Niinikoshi J, Gerdin B, Lebel L. Stimulation of wound healing by EGF. Ann Surg 1986;203:379-81.

13. Andresen JL, Ledet T, Ehlers N. Keratocyte migration and peptide growth factors. Curr Eye Res 1997;16:605-13.

14. Beaubien J, Boisjoly H, Gagnon P, Guidoin R. Mechanical properties of the rabbit cornea during wound healing after treatment with epidermal growth factor. Can J Ophthalmol 1994;29:61-5.
15. Sheardown H, Wedge C, Chou L, Apel R, Rootman DS, Cheng YL. Continuous epidermal growth factor delivery in corneal epithelial wound healing. Invest Ophthalmol Vis Sci 1993;34:3593-600.

16. Türkyilmaz A, Çelebi N, Gönül B, Alkan-Önyüksel H. Physical characterization and stability of a microemulsion for potential oral administration of a peptide. In: Hincal A, Kas S, editors. Biomedical science and technology: recent developments in the pharmaceutical and medical sciences. New York: Plenum Press, 1998:65-72.

17. Gönül B, Söylemezoğlu T, Babül A, Çelebi N. Effects of epidermal growth dosage forms on mice full-thickness skin wound zinc levels and relation to wound strength. J Pharm Pharmacol 1998;50:641-4.

18. Leibowitz HM, Morello S, Stern M, Kupferman A. Effect of topically administered epidermal growth factor on corneal wound strength. Arch Ophthalmol 1990;108:734-7.

19. Gönül B, Erdoğan D, Bilgihan K, Özoğul C. The effect of artificial tear solutions on wound healing in full-thickness corneal incisions. Acta Physiol Hung 1998;85:251-40.

20. Berger J, Shepard D, Morrow F, Taylor A. Relationship between dietary intake and tissue levels of reduced and total vitamin C in the nonscorbutic guineapig. J Nutr 1989;119:734-40.

21. Kiliç N, Gönül B, Aldemir H, Koz M. Increases in acid proteinase and breaking strength during wound healing. GUEDE J of Pharm Gazi 1994;11:91-6.

22. Gönül B, Koz M, Ersöz G, Kaplan B. Effect of EGF on the corneal wound healing of alloxan diabetic mice. Exp Eye Res 1992;54:519-24.

23. Gönül B, Erdoğan D, Özoğul C, Koz M, Babül A, Çelebi N. Effect of EGF dosage forms on alkali burned corneal wound healing of mice. Burns 1995;21:7-10.

24 Anlar S, Çapan Y, Hincal A. Bioadhesive controlled release systems. II. Experimental methods for determination of bioadhesive dosage forms. Fabad J Pharm Sci 1992;17:277-97.

25. Lee VHL. Peptide and protein delivery. New York: Marcel Dekker, 1991:4-5.

26. Zhang Y, Liou GI, Gulati AK, Akhtar RA. Expression of phosphatidylinositol 3-kinase during EGF-stimulated wound repair in rabbit corneal epithelium. Invest Ophthalmol Vis Sci 1999;40:2819-26.

27. Ohji M, Sundar Raj N, Thoft RA. Transforming growth factor-beta stimulates collagen and fibronectin synthesis by human corneal stromal fibroblasts in vitro. Curr Eye Res 1993;12:703-9.

28 Rose RC, Bode AM. Ocular ascorbate transport and metabolism. Comp Biochem Physiol 1991;100:273-85.

29. Cohen K, Diegelman RF, Lindblad WJ. Wound healing: biochemical and clinical aspects. Philadelphia: WB Saunders, 1992:254-61.

30. Saika S. Ascorbic acid and proliferation of cultured rabbit keratocytes. Cornea 1993;12:191-8. 